\title{
The genetic basis of resistance to downy mildew in Cucumis spp.- - latest developments and prospects
}

\author{
Helena Olczak-Woltman • Joanna Marcinkowska • \\ Katarzyna Niemirowicz-Szczytt
}

Received: 4 June 2010 / Accepted: 13 January 2011 /Published online: 12 February 2011

(C) The Author(s) 2011. This article is published with open access at Springerlink.com

\begin{abstract}
Downy mildew, caused by the Oomycete pathogen Pseudoperonospora cubensis, is one of the most destructive diseases of cucumber (Cucumis sativus L.) and muskmelon (C. melo L.). Although the process of pathogenesis is well understood, there are few disease control options available. The development and deployment of resistant cultivars is generally considered to be the best approach to control downy mildew. The recently completed sequencing of the cucumber genome provides a great opportunity for reliable and thorough study of the sequence and function of resistance genes in the Cucurbitaceae, which will help us to understand the resistance mechanisms and metabolic pathways activated by these genes. It can be anticipated that, in the near future, we will have more information about the genetic bases of resistance to downy mildew in Cucumis, which will facilitate efforts to breed for resistance to this pathogen.
\end{abstract}

Keywords Cucumis melo · Cucumis sativus · Disease .

Pseudoperonospora cubensis

\section{Introduction}

The genus Cucumis, one of the 118 genera in the family Cucurbitaceae, is comprised of 32 species, of which

H. Olczak-Woltman $(\bowtie) \cdot K$. Niemirowicz-Szczytt

Department of Plant Genetics, Breeding and Biotechnology,

Warsaw University of Life Sciences,

ul. Nowoursynowska 159 ,

02-776 Warsaw, Poland

e-mail: helenaolczak@interia.pl

J. Marcinkowska

Department of Plant Pathology,

Warsaw University of Life Sciences,

ul. Nowoursynowska 159 ,

02-776 Warsaw, Poland cucumber (C. sativus L.) and muskmelon (C. melo L.) are the most important economically (Lebeda et al. 2006; Criswell 2008). There are about 45 different pathogens of Cucumis species. Because the fruits of cucumber and muskmelon are used primarily for fresh consumption, the application of pesticides is risky, as it may result in unacceptable levels of pesticide residue. Breeding for disease resistance is the preferred means of controling diseases in cucumber and muskmelon. Disease-resistance breeding efforts have been targeted predominantly against viral diseases, bacterial angular leaf spot (caused by Pseudomonas syringae pv. lachrymans), downy mildew (caused by Pseudoperonospora cubensis), and powdery mildew (caused by Sphaerotheca fuliginea and Erysiphe cichoracearum). Among those, downy mildew requires special attention, as it is the most destructive disease of the Cucumis species (Lebeda et al. 2006).

Downy mildew was observed to cause disease on cucumbers and melons as early as the 19th century, but it was not until the mid-1980s that it occurred on an economically significant scale (Colucci et al. 2006). A severe outbreak of downy mildew occurred on melons in France in 1984 (Pitrat and Blancard 1988). In 1985, the disease reached epidemic levels in cucumbers grown in Central-Eastern Europe. It became a serious problem in the USA starting in 2004 (Colucci et al. 2006). Nowadays, yearly downy mildew epidemics threaten cucumber production in up to 80 countries and muskmelon production in over 50 countries, causing significant economic losses (Lebeda and Urban 2004; Colucci et al. 2006).

\section{The pathogen and pathogenesis}

The causal organism of cucurbit downy mildew is $P$. cubensis (Berk. et Curt.) Rostov., an Oomycete that belongs 
to the kingdom Chromista, phylum Heterokontophyta, class Oomycetes, order Peronosporales, family Peronosporaceae, genus Pseudoperonospora (Göker et al. 2007; Kirk et al. 2008; Bouwmeester et al. 2009). P. cubensis is an obligate parasite that overwinters in warm regions. The dispersal of sporangia is aided by wind and rain (Lebeda and Urban 2004). The first symptoms appear on the adaxial surface of older leaves as light-green or yellow, angular in shape, pinpoint lesions that are restricted by the veins. As the disease progresses, the lesions become first chlorotic and later necrotic, causing a decrease in photosynthesis, and, ultimately, resulting in the desiccation and death of the infected leaf. Light greyish-blue sporangiophores may be observed on the abaxial surface of the infected leaf, especially during periods of high relative humidity. Severely infected plants produce small, misshapen fruit that may not mature, and, in the case of melons, the fruit has low sugar content (Pitrat et al. 1998).

The sporangiophores of $P$. cubensis are produced by intercellular mycelium and are extruded onto the leaf surface via stomata. At first, they are poorly branched and, later, they become dichotomous. Each branch of a sporangiophore terminates with a sporangium (zoosporangium), in which zoospores are produced. Zoospores are the primary source of infection. They are grey, yellowish, or purple in color, ellipsoidal in shape, and measure 20$40 \mu \mathrm{m} \times 14-25 \mu \mathrm{m}$. The zoospores are mobile by means of two flagella of unequal lengths. The zoospores swim in a film of water and enter leaf tissue via stomata to establish infection (Bouwmeester et al. 2009). The disease symptoms become visible 4-12 days after infection, depending on the light intensity, temperature, humidity, and inoculum concentration. Under optimal conditions (light $\sim 50 \mathrm{~W} \times \mathrm{m}^{-2}$, temperature $\sim 20^{\circ} \mathrm{C}$ day and $\sim 15^{\circ} \mathrm{C}$ at night, and at least $6 \mathrm{~h}$ of $100 \%$ relative humidity per day), symptoms appear as early as four days after inoculation (Lange et al. 1989).

\section{Pathotypes}

Initial studies of variability among isolates of $P$. cubensis were performed by Thomas et al. (1987), who reported the existence of five pathotypes among isolates collected in Israel, Japan, and the USA. These studies were based on compatible reactions with species of Cucumis, Citrullus, and Cucurbita. Cohen et al. (2003) reported a sixth pathotype, isolated in Israel. Shetty et al. (2002) found that European and North American pathotypes were more closely related, and that Asian pathotypes were more distinct. Lebeda (1990) observed that the geographic origin and year of isolation played a role in the pathogenicity of $P$. cubensis. In later studies, Lebeda and Gadasová (2002) used differential hosts representing five genera from among the Cucurbitaceae and found 13 different pathotypes in Central Europe. Lebeda and Widrlechner (2003) introduced a set of 12 different hosts (representing different genera, species, and cultivars) to identify pathotypes in P. cubensis. Such broad pathogen variability is typical for the Oomycetes and is also found in Phytophthora infestans and Bremia lactucae (Bouwmeester et al. 2009).

Recently, the genomes of three Oomycetes, P. ramorum, $P$. sojae (Tyler et al. 2006), and P. infestans (Haas et al. 2009), were sequenced. In P. cubensis, the 709-bp rDNA-ITS region was sequenced, showing that it can be divided into three distinct parts: $141 \mathrm{bp}$ of rDNA-ITS1, $406 \mathrm{bp}$ of rDNA-ITS2, with GC contents of $41 \%$ and $46 \%$, respectively, and the relatively conserved $5.8 \mathrm{~S}$ coding region (Wang et al. 2008). The non-coding ITS regions (ITS1 and ITS2) are often used in phylogenetic studies of Oomycetes because of their relatively high sequence variability and because of the availability of polymerase chain reaction (PCR) primers. The rDNA-ITS sequence is almost the same in different isolates of $P$. cubensis, which makes it suitable for use as a molecular marker for species identification (Wang et al. 2008).

\section{Resistance to downy mildew}

Disease resistance can be broadly defined as the host's ability to suppress or inhibit a pathogen's activity (Ton et al. 2006). The most widely observed type of resistance is nonhost resistance, which occurs when the plant is not infected because of a pathogen's inability to establish infection and to cause disease following the initial contact. This kind of resistance is durable and is difficult to overcome by pathogens (Ton et al. 2006; Heath 2009). The second type of resistance is determined by resistance genes. Based on the genetic mechanism involved, this type of resistance can be divided into two categories: race-specific resistance, which displays a gene-for-gene relationship between the host and the pathogen, and race-nonspecific resistance, which usually depends on multiple genes of small individual effect (Ton et al. 2006). The third type of resistance is the induced systemic resistance, ISR (often referred to as systemic acquired resistance, SAR). The ISR is a phenomenon in which a biotic or an abiotic stimulus (e.g., a pathogen infection, activation of plant associated microorganisms, or the application of chemicals) causes an elevation of plant resistance to a specific pathogen, or a group of pathogens. This elevated response is initiated by the production of salicylic or jasmonic acids, or ethylene (Kuć 2006; Tuzun 2006).

Studies of the genetic bases of resistance to P. cubensis resulted in the identification of both single-gene-mediated and polygenically inherited resistance (van Vliet and 
Meysing 1974; Epinat and Pitrat 1994a). The identification of two types of resistance is likely due to the use of different plant materials. It also could be due to the use of different parameters to measure resistance when studying the host-pathogen relationship, such as the suppression of sporulation, or presence or absence of chlorosis/necrosis on the infected leaves. Thomas et al. (1987) measured sporulation as a means of identifying $P$. cubensis pathotypes. Sporulation was also used to identify resistance genes (van Vliet and Meysing 1974) and to evaluate host resistance (Lebeda and Prašil 1994; Lebeda et al. 2007). The percentage of necrotic leaf spots was used to characterize plant material by Neykov and Dobrev (1987) and to identify genes for resistance by Doruchowski and Łąkowska-Ryk (1992).

Other researchers combined these two methods and described resistance as the presence of small, chlorotic lesions with a low level of sporulation (Angelov and Krasteva 2000; Petrov et al. 2000). An investigation by Criswell et al. (2008) showed that the occurrence of necrosis and chlorosis were highly correlated, indicating that these two phenotypes may be a manifestation of the same genetic mechanism. In the same study, abundant sporulation was only moderately correlated with chlorosis and necrosis and, therefore, did not appear to be controlled by the same genetic mechanism. This observation did not hold true when a different pathotype was used, and correlations obtained by measuring chlorosis, necrosis, and sporulation indicated that resistance to that pathotype was controlled by the same genetic mechanism (Criswell et al. 2008). In addition, other researchers found anatomical and cytological factors that contribute to the level of host resistance. Habdas et al. (1996) found that the epidermis in all highly resistant cucumber accessions was covered with a thick cuticle that also partly covered the stomata.

\section{Qualitative (vertical) resistance}

The mode of inheritance of resistance to downy mildew in cucumber has been studied for the past 70 years (Criswell 2008). However, it was not until 1963 that it was elucidated for the first time by Shimizu et al. (1963), who reported three recessive resistance genes in the cucumber cultivar (cv.) 'Aojihai'. Three recessive resistance genes were also reported in studies using different plant material by Doruchowski and Łakowska-Ryk (1992), who designated them as $d m 1, d m 2$, and $d m 3$. On the other hand, van Vliet and Meysing (1974) reported that resistance in cv. 'Poinsett' was determined by one recessive gene $(\mathrm{dm}) \mathrm{CV}$. 'Poinsett' was selected from 197087 plant introduction of Indian origin. The single-gene resistance was later confirmed by Fanourakis and Simon (1987).
In $C$. melo, two complementary, incompletely dominant genes $(P c-1$ and $P c-2)$ were described by Thomas et al. (1988) in the resistant line MR-1. However, using different plant material, Epinat and Pitrat (1989) reported that resistance in melon was controlled by a single dominant gene, designated $P c-3$. The presence of a single dominant gene for resistance was also indicated in studies by Angelov and Krasteva (2000), who stated that, in a susceptible line, the expression of this gene was masked by an epistatic gene.

The research cited above indicates major differences in the understanding of the genetics of resistance to downy mildew in these two host species. In cucumber, resistance to downy mildew is likely to be determined by a recessive gene or genes, whereas in melon, it is likely to be determined by a dominant gene(s). Moreover, in cucumber, there is a correlation between the presence of genes for resistance to downy mildew $(\mathrm{dm})$ and to powdery mildew ( $\mathrm{pm}$ ) (van Vliet and Meysing 1977; Pivovarov 1988). Linkage analysis studies indicate that the $d m$ and $p m$ genes are located either at the same locus or in closely linked loci (Fanourakis 1984). In contrast, resistance to these two diseases in muskmelon is inherited independently (Thomas et al. 1988).

Several studies have identified molecular markers that appear to be linked to cucumber resistance to downy mildew. Horejsi et al. (1999) found four polymorphic random amplified polymorphic DNA (RAPD) markers linked to the $d m$ gene and converted them to sequence characterized amplified region (SCAR) markers. The same authors subsequently identified five additional markers (Horejsi et al. 2000). Recently, Śmiech et al. (2008) described eight RAPD markers that produced polymorphic amplicons in either susceptible or resistant lines of cucumber. In an earlier study, Danin-Poleg et al. (2000) developed 34 simple sequence repeat (SSR) markers for Cucumis and mapped several of them in both cucumber and muskmelon, demonstrating cross-homology between these two species and the potential utility of these markers for comparative mapping between melon and cucumber.

In 2009, the cucumber genome was sequenced independently by two research teams. A team led by Chinese researchers worked on 'Chinese Long' inbred line 9930 and used a combination of the traditional Sanger and nextgeneration Illumina GA sequencing methods (Huang et al. 2009). A team led by Polish scientists worked on 'pickling' inbred line B10 and used the 454 Titanium sequencing method (Wóycicki et al. 2009). The high co-linearity between the cucumber and melon genomes (Huang et al. 2009) has the potential to enable the sequence derived from cucumber to serve as a model system for other species in the Cucumis genus. Identification of map location of the molecular markers linked to downy mildew resistance will help in the identification of the gene sequence, and, in turn, 
may help to elucidate the mechanism of resistance and/or metabolic pathways activated by these genes. Development of high-resolution mapping families, with highly accurate phenotypic data on disease response, is the most important resource that will allow the application of genomic sequences in breeding for increased resistance.

\section{Quantitative (horizontal) resistance}

Resistant phenotypes that do not segregate into discrete categories of resistance are assumed to be under the control of multiple genes for resistance. In general, quantitative resistance that is under polygenic control is more durable than resistance conferred by a single dominant gene (Kelly and Vallejo 2006). However, quantitative inheritance of resistance as measured by disease severity is often characterized by low heritability and is under significant environmental influence (Olczak-Woltman et al. 2009). In fact, in the case of polygenic resistance to cucumber downy mildew, broad-sense heritability was found to be relatively low: $8 \%$ and $17 \%$ for two independent populations analyzed, respectively (Horejsi et al. 2000).

In cucumber, McFerson (1978) noticed that, in the breeding line GY14A, which was also developed using line PI 197097, resistance to downy mildew was polygenic. In muskmelon, the genetics of quantitative resistance to downy mildew was investigated by Epinat and Pitrat (1994a) with the use of a diallel cross with heterozygotic progenies of MR-1 and other lines of similar origin. The results indicated the presence of multiple alleles, a possible presence of double epistasis, and continuous variation for the ranking of resistance level varying from high resistance to high susceptibility. The authors concluded that resistance seemed to be controlled by numerous additive loci. In another study, the same authors found that $84-99 \%$ of variation in the resistance was due to additive gene action, while dominance or epistasis accounted only for $3 \%$ and $8 \%$ of the observed variation, respectively (Epinat and Pitrat 1994b). The quantitative resistance to downy mildew in muskmelon is positively correlated with increased peroxidase activity. Reuveni et al. (1990) observed that individuals with high peroxidase activity were resistant to P. cubensis when inoculated.

Regions that encode genes of partial effect are often referred to as quantitative trait loci (QTL). Some QTLs encode genes for race-specific resistance, whereas others for race-nonspecific resistance (Young 1996). The application of QTL analysis can be highly valuable in breeding for resistance, as it reveals the location of loci controling disease resistance and, ultimately, may allow markerassisted selection for resistance without confounding effects of environmental factors (Kelly and Vallejo 2006). The first
QTLs for resistance to downy mildew in muskmelon were identified by Perchepied et al. (2005), who mapped 11 QTL markers on six linkage groups on an unsaturated linkage map of this species.

\section{Sources of resistance}

Plant sources with the highest levels of resistance to downy mildew originate from the Far East. Highly resistant accessions of cucumber and muskmelon were found in India, China, and Japan (Pitrat et al. 1989; Staub et al. 1989).

The most resistant muskmelon lines, PI 124111 (as well as MR-1 and PI $124111 \mathrm{~F}$, which were selected from PI 124111) and PI 124112, were reported to be resistant to all pathotypes of $P$. cubensis and to Alternaria sp., F. oxysporum f. sp. melonis, and S. fuliginea (Thomas et al. 1988; Balass et al. 1992; Pitrat et al. 1996). These accessions are from India; they and lines selected from them are vegetable melons (subsp. agrestis var. momordica). Their suite of inferior fruit quality traits poses a challenge for the development of dessert melons with resistance to downy mildew.

Resistance in the accession PI $124111 \mathrm{~F}$ is manifested by the induction of a hypersensitive response that leads to the deposition of callose along the inner surface of the host cell walls, resulting in an encasement of the Oomycete haustoria within callose-like deposits, and massive lignification of the host cell (Cohen et al. 1989). Balass et al. (1992) found that the resistant line PI $124111 \mathrm{~F}$ contained a $45-\mathrm{kD}$ protein (P45) that was not present in the susceptible genotypes. Taler et al. (2004) conducted partial sequencing of the P45 protein and showed that it was a peroxisomal aminotransferase enzyme. Genes that encode this type of protein enhance the level of enzymatic activity of the host and, therefore, are referred to as enzymatic resistance $(e R)$ genes. Transformation of a susceptible $C$. melo line with a gene construct carrying $e R$ genes (At1 and At2) resulted in a line highly resistant to P. cubensis (Taler et al. 2004). Homologs of the At genes, which could be candidates for downy mildew resistance genes, have recently been identified in the cucumber genome (Huang et al. 2009).

Because high levels of resistance were generally not found in cucumber, Lebeda et al. (1996) made an attempt to transfer resistance from the melon line MR-1 to cucumber using a conventional crossing technique, but the interspecific cross was unsuccessful. The potential sources of resistance in cucumber are completely homozygous double haploid lines (Sztangret-Wiśniewska et al. 2006). Among other Cucumis species, C. hystrix displays a high level of resistance to $P$. cubensis (Chen et al. 2004). DNA homology studies indicate that C. melo, C. sativus, and $C$. hystrix belong to the same species cluster, that $C$. hystrix is either a progenitor species of $C$. sativus or that they share at 
least a common ancestral lineage (Chung et al. 2006). Recently, genetically stable introgression lines with resistance to downy mildew have been obtained from an interspecific hybridization of $C$. sativus and C. hystrix (Zhou et al. 2009).

\section{Conclusions}

Downy mildew is one of the most destructive diseases of cucumber and muskmelon. The control of this disease with fungicides, although necessary, often does not give satisfactory results. Therefore, breeding for resistance seems to be the most effective way to control this disease. It is easier to introduce resistance genes into the elite breeding lines, inbreds, and cultivars when the genetic basis of the resistance is understood. There is no doubt that the recent sequencing of the cucumber genome will provide the opportunity to acquire, in a short time frame, reliable and accurate information on resistance genes to downy mildew for the Cucurbitaceae, their location, construction, and function. The sequenced genome enables identification of the gene sequences, which, in turn, will enable the elucidation of the resistance mechanism and the metabolic pathways activated by these genes. This will make possible the determination of the conditions in which the genes are activated and of the metabolic pathways that are involved in the expression of resistance. However, because the genetic work on cucumber and melon that has been done so far is fragmentary, stronger co-ordination among various research and breeding centers is recommended to ensure optimal efficiency in future progress.

Open Access This article is distributed under the terms of the Creative Commons Attribution Noncommercial License which permits any noncommercial use, distribution, and reproduction in any medium, provided the original author(s) and source are credited.

\section{References}

Angelov D, Krasteva L (2000) Dominant inheritance of downy mildew resistance in melons. Acta Hort 510:273-275

Balass M, Cohen Y, Bar-Joseph M (1992) Identification of a constitutive $45 \mathrm{kDa}$ soluble protein associated with resistance to downy mildew in muskmelon (Cucumis melo L.), line PI 124111 F. Physiol Mol Plant Pathol 41:387-396

Bouwmeester K, van Poppel PMJA, Govers F (2009) Genome biology cracks enigmas of oomycete plant pathogens. Annu Plant Rev 34:102-133

Chen JF, Moriarty G, Jahn M (2004) Some disease resistance tests in Cucumis hystrix and its progenies from interspecific hybridization with cucumber. In: Lebeda A, Paris HS (eds) Progress in cucurbit genetics and breeding research. Palacky University, Olomouc, pp 189-196
Chung SM, Staub JE, Chen JF (2006) Molecular phylogeny of Cucumis species as revealed by consensus chloroplast SSR marker length and sequence variation. Genome 49:219-229

Cohen Y, Eyal H, Hanania J, Malik Z (1989) Ultrastructure of Pseudoperonospora cubensis in muskmelon genotypes susceptible and resistant to downy mildew. Physiol Mol Plant Pathol 34:27-40

Cohen Y, Meron I, Mor N, Zuriel S (2003) A new pathotype of Pseudoperonospora cubensis causing downy mildew in cucurbits in Israel. Phytoparasitica 31:458-466

Colucci SJ, Wehner TC, Holmes GJ (2006) The downy mildew epidemic of 2004 and 2005 in the Eastern United States. In: Holmes GJ (ed) Proceedings of Cucurbitaceae 2006. Universal Press, Raleigh, NC, pp 403-410

Criswell AD (2008) Screening cucumber (Cucumis sativus) for resistance to downy mildew (Pseudoperonospora cubensis). MSc thesis. North Carolina State University, Raleigh, NC, USA

Criswell AD, Wehner TC, Kłosińska U, Kozik E (2008) Use of sporulation and other leaf and vine traits for evaluation of resistance to downy mildew in cucumber. In: Pitrat $M$ (ed) Proceedings of the IX Eucarpia meeting on genetics and breeding of Cucurbitaceae. INRA, Avignon, France, pp 433-440

Danin-Poleg Y, Reis N, Baudracco-Arnas S, Pitrat M, Staub JE, Oliver $\mathrm{M}$ et al (2000) Simple sequence repeats in Cucumis mapping and map merging. Genome 43:963-974

Doruchowski RW, Łąkowska-Ryk (1992) Inheritance of resistance to downy mildew (Pseudoperonospora cubensis Berk \& Curt) in Cucumis sativus. In: Doruchowski RW (ed) Proceedings of the V Eucarpia Cucurbitaceae symposium. Skierniewice-Warszawa, pp 132-138

Epinat C, Pitrat M (1989) Inheritance of resistance of three lines of muskmelon (Cucumis melo) to downy mildew (Pseudoperonospora cubensis). In: Thomas CE (ed) Evaluation and enhancement of cucurbit germplasm. Cucurbitaceae Proceedings, Charleston, SC, pp 133-135

Epinat C, Pitrat M (1994a) Inheritance of resistance to downy mildew (Pseudoperonospora cubensis) in muskmelon (Cucumis melo). I. Analysis of a $8 \times 8$ diallel table. Agronomie 14:239-248

Epinat C, Pitrat M (1994b) Inheritance of resistance to downy mildew (Pseudoperonospora cubensis) in muskmelon (Cucumis melo). II. Generation means analysis of 5 genitors. Agronomie 14:249-257

Fanourakis NE (1984) Inheritance and linkage studies of the fruit epidermis structure and investigation of linkage relations of several traits and of meiosis in cucumber. $\mathrm{PhD}$ thesis. University of Wisconsin, Madison, USA

Fanourakis NE, Simon PW (1987) Analysis of genetic linkage in the cucumber. J Hered 78:238-242

Göker M, Voglmayr H, Riethmüller A, Oberwinkler F (2007) How do obligate parasites evolve? A multi-gene phylogenetic analysis of downy mildews. Fungal Genet Biol 44:105-122

Haas BJ, Kamoun S, Zody MC, Jiang RH, Handsaker RE, Cano LM et al (2009) Genome sequence and analysis of the Irish potato famine pathogen Phytophthora infestans. Nature 461:393-398

Habdas H, Staniaszek M, Doruchowski RW, Łakowska-Ryk E (1996) Anatomical and cytological mechanism of cucumber resistance and susceptibility to downy mildew (Pseudoperonospora cubensis Berk, Curt). In: Gómez-Guillamón ML, Soria $\mathrm{C}$, Cuartero J, Torès JA, Fernandez-Munoz R (eds) Cucurbits towards 2000. Proceedings of the VI Eucarpia meeting on cucurbit genetics and breeding, Málaga, pp 263-268

Heath MC (2009) A personal perspective of the last 40 years of plant pathology: emerging themes, paradigm shifts and future promise. Annu Plant Rev 34:1-15

Horejsi T, Box JM, Staub JE (1999) Efficiency of randomly amplified polymorphic DNA to sequence characterized amplified region marker conversion and their comparative polymer- 
ase chain reaction sensitivity in cucumber. J Am Soc Hort Sci 124:128-135

Horejsi T, Staub JE, Thomas C (2000) Linkage of random amplified polymorphic DNA markers to downy mildew resistance in cucumber (Cucumis sativus L.). Euphytica 115:105-113

Huang S, Li R, Zhang Z, Li L, Gu X, Fan W et al (2009) The genome of the cucumber, Cucumis sativus L. Nat Genet 41:1275-1281

Kelly JD, Vallejo V (2006) QTL analysis of multigenic disease resistance in plant breeding. In: Tuzun S, Bent E (eds) Multigenic and induced systemic resistance in plants. Springer Science, New York, pp 21-48

Kirk PM, Cannon PF, Minter DW, Stalpers JA (2008) Dictionary of the fungi. CBS, The Netherlands

Kuć J (2006) What's old and what's new in concepts of induced systemic resistance in plants, and its application. In: Tuzun $\mathrm{S}$, Bent E (eds) Multigenic and induced systemic resistance in plants. Springer Science, New York, pp 9-20

Lange L, Edén U, Olson LW (1989) Zoosporogenesis in Pseudoperonospora cubensis, the causal agent of cucurbit downy mildew. Nordic J Bot 8:497-504

Lebeda A (1990) Biology and ecology of cucurbit downy mildew. In: Lebeda A (ed) Cucurbit downy mildew. Czechoslovak Academy of Sciences, Prague, pp 13-46

Lebeda A, Gadasová J (2002) Pathogenic variation of Pseudoperonospora cubensis in the Czech Republic and some other European countries. In: Nishimura S, Ezura H, Matsuda T, Tazuke A (eds) Proceedings of the 2nd International Symposium on Cucurbits. http://www. actahort.org/books $/ 588$

Lebeda A, Prášil J (1994) Susceptibility of Cucumis sativus cultivars to Pseudoperonospora cubensis. Acta Phytopathol Entomol Hung 29:89-94

Lebeda A, Urban J (2004) Distribution, harmfulness and pathogenic variability of cucurbit downy mildew in the Czech Republic. Acta Fytotech Zootech 7:170-173

Lebeda A, Widrlechner M (2003) A set of Cucurbitaceae taxa for differentiation of Pseudoperonospora cubensis pathotypes. J Plant Dis Protect 110:337-349

Lebeda A, Křistková E, Kubaláková M (1996) Interspecific hybridization of Cucumis sativus $\times$ Cucumis melo as a potential way to transfer resistance to Pseudoperonospora cubensis. In: Gómez-Guillamón ML, Soria C, Cuartero J, Torès JA, FernandezMunoz R (eds) Cucurbits towards 2000. Proceedings of the VI Eucarpia meeting on cucurbit genetics and breeding, Málaga, pp 3137

Lebeda A, Widrlechner MP, Urban J (2006) Individual and population aspects of interactions between cucurbits and Pseudoperonospora cubensis: pathotypes and races. In: Holmes GJ (ed) Proceedings of Cucurbitaceae 2006. Universal Press, Raleigh, NC, pp 453-467

Lebeda A, Štěpánková J, Krišková M, Widrlechner MP (2007) Resistance in Cucumis melo germplasm to Pseudoperonospora cubensis pathotypes. In: Lebeda A, Spencer-Philips PTN (eds) Advances in downy mildew research. Proceedings of the 2 nd International Downy Mildews Symposium. Olomouc, pp 157167

McFerson JR (1978) A screening procedure for determining levels of resistance in cucumber. MSc thesis, Texas A\&M University, USA

Neykov S, Dobrev D (1987) Introduced cucumber cultivars relatively resistant to Pseudoperonospora cubensis in Bulgaria. Acta Hortic 220:115-119

Olczak-Woltman H, Bartoszewski G, Mądry W, Niemirowicz-Szczytt K (2009) Inheritance of resistance to angular leaf spot (Pseudomonas syringae pv. lachrymans) in cucumber and identification of molecular markers linked to resistance. Plant Pathol 58:145151

Perchepied L, Bardin M, Dogimont C, Pitrat M (2005) Relationship between loci conferring downy mildew and powdery mildew resistance in melon assessed by quantitative trait loci mapping. Phytopathology 95:556-565

Petrov L, Boogert K, Sheck L, Baider A, Rubin E, Cohen Y (2000) Resistance to downy mildew, Pseudoperonospora cubensis, in cucumbers. Acta Hortic 510:203-209

Pitrat M, Blancard D (1988) Some aspects of resistance of muskmelon to downy mildew. In: Cucurbitaceae 88. Proceedings of the Eucarpia meeting on cucurbit genetics and breeding, AvignonMontfavet, pp 57-62

Pitrat M, Blancard D, Epinat C (1989) A study on the variability of downy mildew and looking for sources of resistance in Cucumis melo. In: Thomas CE (ed), Evaluation and enhancement of cucurbit germplasm. Cucurbitaceae Proceedings, Charleston, SC, pp 137139

Pitrat M, Risser G, Bertrand F, Blancard D, Lecoq H (1996) Evaluation of a melon collection for disease resistance. In: Gómez-Guillamón ML, Soria C, Cuartero J, Torès JA, FernandezMunoz R (eds) Cucurbits towards 2000. Proceedings of the VI Eucarpia meeting on cucurbit genetics and breeding, Málaga, pp 49-58

Pitrat M, Dogimont C, Bardin M (1998) Resistance to fungal diseases of foliage in melon. In: McCreight JD (ed) Evaluation and enhancement of cucurbit germplasm. Cucurbitaceae Proceedings, Pacific Grove, CA, pp 167-173

Pivovarov VF (1988) Cucumber breeding for general adaptive ability and resistance to diseases. In: Cucurbitaceae 88. Proceedings of the Eucarpia meeting on cucurbit genetics and breeding, Avignon-Montfavet, pp 69-74

Reuveni R, Shimoni M, Karchi Z (1990) A rapid assay for monitoring peroxidase activity in melon as a marker for resistance to Pseudoperonospora cubensis. J Phytopathol 129:333-338

Shetty NV, Wehner TC, Thomas CE, Doruchowski RW, Shetty KPV (2002) Evidence for downy mildew races in cucumber tested in Asia, Europe and North America. Sci Hortic-Amsterdam 94: 231-239

Shimizu S, Kanazawa K, Kato A (1963) Studies on the breeding of cucumber for resistance to downy mildew. Part 2. Difference of resistance to downy mildew among the cucumber varieties and the utility of the cucumber variety resistance to downy mildew. Bul Hort Res Sta Jpn 2:80-81

Śmiech M, Sztangret-Wiśniewska J, Gałecka T, Korzeniewska A, Marzec L, Kołakowska G, Piskurewicz U, Niemirowicz-Szczytt K (2008) Potential use of RAPD markers in characteristics of cucumber (Cucumis sativus L.) haploids and double-haploids. Acta Soc Bot Pol 77:29-34

Staub JE, Barczyńska H, van Kleinwee D, Palmer M, Łąkowska E, Dijkhuizen A (1989) Evaluation of cucumber germplasm for six pathogens. In: Thomas CE (ed) Evaluation and enhancement of cucurbit germplasm. Cucurbitaceae Proceedings, Charleston, SC, pp 149-153

Sztangret-Wiśniewska J, Galecka T, Korzeniewska A, Marzec L, Kolakowska G, Piskurewicz U, Smiech M, Niemirowicz-Szczytt K (2006) Characteristics of double-haploid cucumber (Cucumis sativus L.) lines resistant to downy mildew (Pseudoperonospora cubensis [Berk et Curt.] Rostovzev). In: Holmes GJ (ed) Proceedings of Cucurbitaceae 2006. Universal Press, Raleigh, NC, pp 515-526

Taler D, Galperin M, Benjamin I, Cohen Y, Kenigsbuch D (2004) Plant $e R$ genes that encode photorespiratory enzymes confer resistance against disease. Plant Cell 16:172-184

Thomas CE, Inaba T, Cohen Y (1987) Physiological specialization in Pseudoperonospora cubensis. Phytopathology 77:1621-1624

Thomas CE, Cohen Y, McCreight JD, Jourdain EL, Cohen S (1988) Inheritance of resistance to downy mildew in Cucumis melo. Plant Dis 72:33-35

Ton J, Pieterse CMJ, van Loon LC (2006) The relationship between basal and induced resistance in Arabidopsis. In: Tuzun S, Bent E 
(eds) Multigenic and induced systemic resistance in plants. New York, Springer Science, pp 197-224

Tuzun S (2006) Terminology related to induced systemic resistance: incorrect use of synonyms may lead to a scientific dilemma by misleading interpretation of results. In: Tuzun S, Bent E (eds) Multigenic and induced systemic resistance in plants. Springer Science, New York, pp 1-8

Tyler BM, Tripathy S, Zhang X, Dehal P, Jiang RH, Aerts A et al (2006) Phytophthora genome sequences uncover evolutionary origins and mechanisms of pathogenesis. Science 313:12611266

van Vliet GJA, Meysing WD (1974) Inheritance of resistance to Pseudoperonospora cubensis Rost. in cucumber (Cucumis sativus L.). Euphytica 23:251-255

van Vliet GJA, Meysing WD (1977) Relation in the inheritance of resistance to Pseudoperonospora cubensis Rost. and Sphaerotheca fuliginea Poll. in cucumber (Cucumis sativus L.). Euphytica 26:793-796

Wang N, Ma Y, Yang C, Dai G, Wang Z (2008) rDNA-ITS sequence analysis of pathogens of cucumber downy mildew and cucumber powdery mildew. Front Agric China 2:317-320

Wóycicki R, Witkowicz J, Pawełkowicz M, Siedlecka E, Gutman W, Pląder W, Seroczyńska A, Smiech M, Niemirowicz-Szczytt K, Karpiński S, Malepszy S, Przybecki Z (2009) Sequencing, assembly and annotation of cucumber (Cucumis sativus L.) genome. Plant and Animal Genomes XVII Conference, San Diego, CA. http://csgenome.sggw.pl/

Young ND (1996) QTL mapping and quantitative disease resistance in plants. Annu Rev Phytopathol 34:479-501

Zhou X-H, Qian C-T, Lou Q-F, Chen J-F (2009) Molecular analysis of introgression lines from Cucumis hystrix Chakr. to C. sativus $\mathrm{L}$. Sci Hortic 119:232-235 